Agro-Science Journal of Tropical Agriculture, Food, Environment and Extension Volume 21 Number 1 (January 2022) pp. 1 - 6

ISSN 1119-7455

\title{
EFFECT OF EXCHANGE RATE VOLATILITY ON RWANDAN COFFEE PRICE AND EXPORT VOLUMES
}

\author{
${ }^{* 1}$ Kabayiza A., ${ }^{2}$ Muhire R., ${ }^{1}$ Nsabimana S., ${ }^{3}$ Kabarungi M., ${ }^{4}$ Ningabire Y.B. and ${ }^{1}$ Niyitanga F. \\ ${ }^{1}$ Department of Rural Development \& Agricultural Economics, University of Rwanda, Rwanda \\ ${ }^{2}$ Business Adviser, Agriterra, Rwanda \\ ${ }^{3}$ Department of Animal Production, University of Rwanda, Rwanda \\ ${ }^{4}$ Ministry of Trade \& Industry, Rwanda
}

*Corresponding author’s email: akabayiza@gmail.com; ORCID: https://orcid.org/0000-0001-6224-7605

\begin{abstract}
The main strategy of Rwanda for having a steady growth in coffee export value and revenues was increased sales of speciality coffee. However, global coffee prices are often volatile and Rwanda has little control over the fluctuating global prices. This paper analysed the effect of exchange rate volatility on the price and exports of Rwanda coffee. In order to respond to this question, the monthly time series data on bilateral Rwanda coffee exports and real effective exchange rates from January 2001 to December 2016 were analysed. The cointegration methods and error correction model using the autoregressive distributed lag procedure andGlosten, Jagannathan, and Runkle-Generalized Autoregressive Conditional Heteroskedasticity (GJR-GARCH) model were used to analyse the data. The findings showed that the exchange rate volatility resulted in an increase in Rwandan coffee export price in the long run by $1.5 \%$ and a decrease in the short run by $0.2 \%$. The findings also showed that the exchange rate volatility affected coffee export volumes in the long run and the short run by $44.4 \%$ and $3.8 \%$, respectively. The real income in importing countries increased coffee prices in the long run by $3.0 \%$ and coffee export volumes in the long run and the short run by $26.9 \%$ and $38.5 \%$, respectively. A review of monetary policy to address the issue of volatility and hedging system adoption in the Rwanda coffee sector should be done in order to stabilize the exchange rate and to consequently avoid its bad effects on coffee price and export volumes.
\end{abstract}

Key words: Rwandan coffee price, exchange rate volatility, real exchange rate, export volumes

\section{INTRODUCTION}

The agriculture sector remains the engine of the Rwandan economy. According to the Ministry of Agriculture and Animal Resources of Rwanda, this sector employs $64 \%$ of the country's labour force and provides around a third of the National Gross Domestic Product (GDP) (MINAGRI, 2020). Coffee and tea stand as major agricultural export crops and origin of foreign currencies since 1930 (NAEB, 2011). Both coffee and tea account for $81 \%$ of agricultural export earnings (Broka et al., 2016). Also, both coffee and tea play a major role in the monetization of the rural economy (RDB, 2021). Rwandan coffee has been distinguished as the best brewed in the world (MINAGRI, 2021). It has scooped some international awards such as "Best of the Best" and "Coffee Lover's Choice" in a competition that attracted brands from nine countries around the world (RDB, 2021). It was also among the top 10 winners of the International Barista Championship that took place in China in 2019. In 2018, Rwandan coffee started trading on Alibaba, one of the world's largest e-commerce platforms.So far, sales volumes of Rwandan coffee have grown by
$700 \%$ on Tmall Global, Alibaba's cross-border B2C platform (RDB, 2021). Generally, Rwanda exports over $60 \%$ of its coffee to the European Union (EU), $20 \%$ to the United State of America (US), and small quantities to the Asia/Pacific region (NAEB, 2019). The national targets for coffee export value growth indicates a shift from 69.7 million USD in 2018 to 104.3 million USD by 2024 (NAEB, 2019).

Although Rwanda has adopted the strategy to have steady growth in coffee export value by increasing sales of speciality coffee, its share in the international markets remains insignificant because of small coffee export volumes (NAEB, 2019). Global coffee prices are often volatile and Rwanda has little control over fluctuating global prices (World Bank Group, 2019). In such a situation, an internal exchange rate policy could help the country to survive external incidences. Exchange rate volatility is likely to impact the exports by creating gains or losses to farmers and exporters (Faridi, 2012). To some extent, the total value of export earnings does not depend only on the volume of coffee exports traded abroad but also on the worth paid for players in the coffee value chain.

Please cite as: Kabayiza A., Muhire R., Nsabimana S., Kabarungi M., Ningabire Y.B. and Niyitanga F. (2022). Effect of exchange rate volatility on Rwandan coffee price and export volumes. Agro-Science, 21 (1), 1-6. DOI: https://dx.doi.org/10.4314/as.v21i1.1 
The exchange rate policy was introduced in 1995 (NBR, 2015). The objective of the regime was to stabilize the exchange rate and prices, and to enhance economic growth as well as link the national exchange market to the world market (Mukunzi, 2004). From 2000 till today, the share of coffee exports to the GDP has considerably been fluctuating (NISR, 2015; NAEB, 2019). Although theory supports that exchange rates and exchange policies have a huge bearing on the performance of the country's exports, there is no empirical evidence to reveal the causal effect and extent of the volatility in exchange rate. This study investigated the effect of the exchange rate volatility on Rwanda coffee price and export volumes.

\section{MATERIALS AND METHODS}

The coffee monthly time series data on bilateral exports and real effective exchange rate from January 2001 to December 2016 for Rwandan coffee was used. The time-series data were retrieved from the websites of the National Bank of Rwanda (NBR), National Agricultural Export Development Board (NAEB), Food and Agricultural Organization Statistics (FAO stat.), National Institute of Statistics of Rwanda (NISR) and World Bank Development Indicators. The unit of measurement was metric ton (MT) for coffee exports. Coffee exports are denoted by CEXP and expressed in logarithmic form. Coffee export prices were the value of one kilogram in USD (USD $\mathrm{kg}^{-1}$ ) and they were denoted by CP in the logarithmic form as well. Real effective exchange rate (REER) was an average of a basket of foreign currencies while a nominal effective exchange rate (NEER) was an inverse average of asymptotic trade weight. The REER is the regulator of the NEER by the means of a specific foreign price level. The REER was computed as a product of nominal effective exchange rate and domestic consumer price index divided by a foreign consumer price index. The real exchange rate can make the Rwandan exports cheaper and competitive on the world market when it is increased and vice versa. The real effective exchange rate (REER) was computed as:

$$
R E E R=\sum_{i}^{n} R_{t} \omega_{i} ;
$$

where $\omega_{i}$ was the country $i$ 's share of trade with Rwanda and $\varepsilon_{i}$ was the real exchange rate defined as:

$$
R_{t}=\varepsilon_{i} \times \frac{C P I_{D}}{C P I_{F}}
$$

where $\varepsilon_{i}$ was the nominal exchange rate (how much of the trading partner's currency was needed to obtain 1 Rwandan franc), $\mathrm{CPI}_{\mathrm{D}}$ was the domestic consumer price index and $\mathrm{CPI}_{\mathrm{F}}$ was the consumer price index of the trade partner. Real foreign income proxied by importer industrial production (IP) was used as an indicator of demand for Rwandan exports. Volatility was defined as the level of change in the trading price series over time as measured by the standard deviation of logarithmic return. $h_{t}$ denoted the measure of real exchange rate volatility to measure the risk associated with exchange rate fluctuations. A dummy variable, i.e., $S$, included represents the seasonality. In agriculture, the seasons affect the production of crops and consequently the exports. There are normally three season of coffee all over the world: January to March (Season 1), March to September (Season 2) and, September to December (Season 3).

The data was analyzed using Glosten, Jagannathan, and Runkle-Generalized Autoregressive Conditional Heteroskedasticity (GJR-GARCH) model and the co-integration methods and error correction model. The Augmented Dickey-Fuller Test (ADF) was used to test the stationary of time series data. The GJR-GARCH model suggested by Glosten et al. (1993) was used to examine the dynamic conditional exchange rate volatility. The conditional variance was specified as a GJRGARCH process using equations 1, 2, 3 and 4 which are conventional GARCH models:

$$
\begin{aligned}
& A \phi_{m}(L) R_{t}=\gamma_{0}+A \phi_{m}(L) e_{1, t} \ldots \ldots \\
& e_{1, t}=Z_{t} \sqrt[2]{h_{t}} \\
& Z_{t} \sim N(0,1) \\
& h_{t}=W_{0}+\sum_{j=0}^{q} \alpha_{j} e_{1, t-j}^{2} \sum_{k=1}^{p} \beta_{k} h_{t-k} \text {. }
\end{aligned}
$$

where $A \phi_{m}(L) R_{t}$ is the first difference in the natural logarithm of the real exchange rate. It represents the percentage fluctuations in the monthly real exchange rates. Then $W_{0}, \alpha_{j}, \beta_{k}$ are parameters to be estimated while $e_{1, t}$ are the residuals. $Z_{t}$ and $h_{t}$ are the model's conditional variance and $h_{t}$ varies over time and is modeled as a function of the lagged squared residuals $e_{1, t-k}^{i}$ as well as the conditional variance $h_{t-k}^{i}$. The GJR-GARCH conditional variance specification maintains the tractability of the conventional GARCH model 4 while accommodating a leverage effect by adding a term to permit asymmetry in the GARCH model 4:

$$
\begin{aligned}
h_{t}= & W_{0}+\sum_{j=0}^{q} \alpha_{j} e_{1, t-j}^{2} \sum_{k=1}^{p} \beta_{k} h_{t-k}+ \\
& \eta S_{t-1} e_{1, t-j}^{2}
\end{aligned}
$$

where $S_{t-1}$ is the leverage effect variable and it takes on the value of 1 if $e_{1, t-1}<0$, and $s_{t-1}=0$ otherwise. The leverage effect is captured by the parameter $\eta$; if $\eta=0$ the GJR model reduces to the conventional GARCH specification. The imposed restrictions are $W_{0}>0 ; \beta_{k} \geq 0, \forall k ; \alpha_{j} \geq 0, \forall j$, and $\eta \geq 0$ which strictly ensures a positive conditional variance. The value of the summation of the parameters in equation 5 may be interpreted as a measure of the persistence of variance. The real exchange rate in first difference $\left(R_{t}\right)$ in equation 1 is then used to derive the successive periods $R_{i, t-k 2}^{e}$ for $k_{2}$-periodahead and $R_{i, t-k 3}^{e}$ for $k_{3}$-period-ahead changes in the expectations of the real exchange rate (conditional variance estimates for exchange rate risk): 


$$
\begin{aligned}
& D L R_{t}^{e}=\gamma_{0} \sum_{i=0}^{k-1} \phi_{1}^{i}+\phi_{1}^{k} D L R_{t-k} \\
& h_{t}^{e}=w_{0} \sum_{i=0}^{k-1} \beta_{1}+\alpha_{1} k_{1}^{k-1} e_{1, t-k}^{2}+\beta_{1}^{k} h_{i, t-k} \ldots \ldots \ldots \ldots \ldots . . .
\end{aligned}
$$

The $D L R_{t}^{e}$ series is then undifferentiated back to exchange rate levels $D L R_{t-k}$ which indicates the expected level of exchange rate while $h_{t}^{e}$ reflects the exchange rate volatility. The expected values are regressors in the model specified in equation 8 .

According to Kenen and Rodrik (1986), DeGrauwe (1988), Pozo (1992) and McKenzie (1999), there exists a long-run relationship between the volume of a countries' exports and the level of economic activity of the importing country, thus the real exchange rate indicates the real competitiveness between the trading countries. Holding this assumption true, the reduced form of the error correction model was specified as:

$$
\begin{aligned}
\operatorname{Ln} Q_{i, t}= & \delta+\sum_{k 1=1}^{a} \delta_{1, k 1} \ln \left(I P_{t-k 1}\right)+ \\
& \sum_{k 2=2}^{b} \delta_{2, k 2} \ln \left(R E E R_{i, t-k 2}^{e}\right)+ \\
& \sum_{k 3=3}^{c} \delta_{3, k 3} \ln \left(h_{i, t-k 3}^{e}\right)+ \\
& \sum_{k 4=4}^{d} \delta_{4, k 4} S_{i, t-4}^{e}+ \\
& \sum_{k 5=5}^{e} \delta_{5, k 5} \ln \left(Q_{i, t-k 5}^{e}\right)+D_{k 4, t}+e_{2 i, t}(8)
\end{aligned}
$$

where $Q_{i, t}$ is Rwanda's coffee export volume to its trading partner country for coffee exports in time $t$, $I P_{t-k 1}$ is the monthly industrial production (real foreign income) of trading partner country for coffee exports, $\left(R E E R_{i, t-k 2}^{e}\right)$ is the expected real effective exchange rate during $t-k_{2}$ period, $h_{i, t-k 3}^{e}$ is the analogous estimates of the expected monthly exchange rate volatility during $t-k_{3}$ period while $S_{i, t-4}^{e}$, represented the seasonality effect during $t-k_{4}$ period. $k_{1}, k_{2}, k_{3}$ and $k_{4}$ are optimal lags and leads that were identified by Hendry and Juselius (2001). The quarterly dummy variable, $D_{k 4, t}$ was introduced to control the seasonality effect that is inherent in export plots. The $Q_{i, t-k 5}^{e}$ is the lagged export volume that was included in the model specification so as to allow for an estimable lag length $(\mathrm{k} 5)$ of the autoregressive persistence in export volumes.

The equation error term, $\varepsilon_{2 i, t}$, is assumed to hold Gauss-Markov properties that the errors do not need to be normal nor do they need to be independent and identically distributed. Variables in equation 8 are natural $\log$ transformation except $D_{k 4, t}$ thus capturing the elasticity effect.

Time series data is inherently non-stationary and unpredictable. According to Gujarati and Porter (2009), time-series data need to be transformed into stationary data to avoid reporting spurious results. The Augmented Dickey-Fuller Test (ADF) was used as stationarity tests. The test was based on $t$-statistics of the coefficient obtained from Ordinary Least Squares (OLS) regressions (Dickey and Fuller, 1979).

The ARDL bounds testing procedure was used to test for the co-integration of variables in equation 8. The general ARDL representation for Rwandan coffee export (Q) was specified as follows:

$$
\begin{aligned}
& \Delta \operatorname{Ln} Q_{i, t}=\delta+\sum_{k 1=1}^{a} \delta_{l, k 1} \Delta \ln \left(I P_{t-k 1}\right)+ \\
& \sum_{k 2=2}^{b} \delta_{2, k 2} \Delta \ln \left(R E E R_{i, t-k 2}^{e}\right)+ \\
& \sum_{k 3=3}^{c} \delta_{3, k 3} \Delta \ln \left(h_{i, t-k 3}^{e}\right)+ \\
& \sum_{k 4=4}^{d} \delta_{4, k 4} S_{i, t-4}^{e}+ \\
& \sum_{k 5=5}^{e} \delta_{5, k 5} \Delta \ln \left(Q_{i, t-k 5}^{e}\right)+ \\
& \beta_{l, k 1} \ln \left(I P_{t-k 1}\right)+\beta_{2, k 2} \ln \left(R E E R_{i, t-k 2}^{e}\right)+ \\
& \beta_{3, k 3} \ln \left(h_{i, t-k 3}^{e}\right)+\beta_{5, k 5} \ln \left(Q_{i, t-k 5}^{e}\right)+\varepsilon_{2 i, t} .
\end{aligned}
$$

The terms that have the gammas are the short-run dynamics while the betas represent long-run estimates. F-test is implemented to test for the co-integration of the variables. The F-test tests the null hypothesis that $\beta_{l, k 1}=\beta_{2, k 2}=\beta_{3, k 3}=\beta_{5, k 5}=0$. Pesaran et al. (2001) provide lower and upper bound critical Fvalues. When the computed lower bound $F$ value is less than the critical $F$ value, the null co-integration hypothesis is not rejected. The null hypothesis is rejected when the computed upper bound $\mathrm{F}$ value exceeds the critical $F$ value. Otherwise, the $F$ test is inconclusive. The error correction model (ECM) was used to analyse the short-run dynamics of the variables when there is co-integration among variables (Maddala, 1992). The ECM was specified as follows and the variables were expressed in logarithms in order to interpret coefficients as elasticities:

$$
\begin{aligned}
& \Delta \operatorname{Ln} Q_{i, t}=\delta+\sum_{k 1=1}^{a} \delta_{1, k 1} \Delta \ln \left(I P_{t-k 1}\right)+ \\
& \sum_{k 2=2}^{b} \delta_{2, k 2} \Delta \ln \left(R E E R_{i, t-k 2}^{e}\right)+ \\
& \sum_{k 3=3}^{c} \delta_{3, k 3} \Delta \ln \left(h_{i, t-k 3}^{e}\right)+\sum_{k 4=4}^{d} \delta_{4, k 4} \Delta S_{k 4, t}+ \\
& \sum_{k 5=5}^{e} \delta_{5, k 5} \Delta \ln \left(Q_{i, t-k 5}^{e}\right)+\pi E C M_{t-1}+\varepsilon_{2 i, t}(10) .
\end{aligned}
$$

\section{RESULTS AND DISCUSSION}

\section{Times Series Properties}

The ADF test was used to analyse the stationarity of time series and make them stationary if it is required. Results in Table 1 indicate that the computed ADF test statistics for the coffee export volumes and the exchange rate volatility exceed the absolute critical value at a $5 \%$ significance level. This implies that the variables were stationaryin level. However, the computed values for ADF for industrial production, coffee export prices, and real effective exchange rate were less than the absolute critical values. This implies that they were not stationary in level and the variables were differentiated. The differentiation of order one I (1) process was found to be sufficient to make them stationary. This means that these three variables became stationaryin the first difference.

Table 1: Unit root test of coffee export function variables

\begin{tabular}{lcc}
\hline \multirow{2}{*}{ Variables } & \multicolumn{2}{c}{ ADF } \\
\cline { 2 - 3 } & Level & Difference \\
\hline Industrial production (IP) & -2.27 & $-20.70^{\mathrm{c}}$ \\
Coffee export (QC) & $-9.38^{\mathrm{c}}$ & $-19.37^{\mathrm{c}}$ \\
Coffee export price (CP) & -3.44 & $-17.85^{\mathrm{c}}$ \\
Exchange rate volatility $\left(h_{t}\right)$ & $-5.05^{\mathrm{c}}$ & $-18.09^{\mathrm{c}}$ \\
Real effective exchange rate (REER) & -2.37 & $-7.07^{\mathrm{c}}$ \\
\hline
\end{tabular}

Source: Authors' calculation. ' denotes rejection of the null hypothesis of a unit root at a $5 \%$ level of significance 


\section{Effect of Exchange Rate Fluctuation on Coffee Price}

Analysis of the long-run relationship between coffee price and industrial production, real exchange rate, and exchange rate volatility

The results in Table 2 show that income in importing countries proxied by industrial production had a significant effect on Rwandan coffee export prices. The elasticity of Rwandan coffee export prices with respect to industrial production was 3.02. This means that a $1 \%$ increase in the amount of industrial production by importing country increases coffee prices by $3.02 \%$ in the long run.

The conditional variance (exchange rate fluctuation or shock) was found to have a positive and statistically significant effect on Rwandan prices in the long run. The results show that a $1 \%$ increase in conditional variance resulted in a $1.5 \%$ increase in Rwandan coffee export prices in the long run. This means that the exchange rate volatility of Rwandan Francs has a positive effect on Rwandan coffee export prices in the long run. This observation is consistent with the findings by Hochman et al. (2011) and Kantike and Eglite (2013) who found that currency exchange rate fluctuations are among the most significant effect of food commodity prices in the world.

Analysis of the short-run relationship between coffee price and industrial production, real exchange rate, and exchange rate volatility

The results in Table 3 show that the probability values of the coefficient of real effective exchange rate regarding the previous period were statistically significant in the short run. This means that the depreciation of Rwandan francs against major trading currencies in the previous period had a greater effect on Rwandan coffee prices. A $1 \%$ increase in the REER of the previous month resulted in an $11.56 \%$ increase in current Rwandan coffee export prices and was statistically significant at $5 \%$. The current findings are inconsistent with the findings of Taghavi and Torkamani (2014) who found that the prior period harmed export prices of the Iranian dates. The exchange rate volatility (shock or conditional variance) in the previous period (month) was found to have a negative and significant effect on Rwandan coffee export prices. This means that a $1 \%$ increase of shock in the previous month resulted in a $0.6 \%$ decrease in current Rwandan coffee export prices in the short run.

Table 2: Estimated long-run coefficients for coffee price function

\begin{tabular}{lcccc}
\hline Variable & Coefficient & Std. error & $t$-value & Prob. \\
\hline IP & $3.02 * *$ & 1.17 & 2.57 & 0.0111 \\
REER & 1.95 & 1.89 & 1.03 & 0.3028 \\
$h_{t}$ & $1.45^{* *}$ & 0.61 & 2.35 & 0.0199 \\
Trend & 0.00 & 0.00 & 0.08 & 0.9368 \\
\hline
\end{tabular}

Source: Authors. **represents treatment means that are significant at 5\% prob. level. IP - Industrial Production, REER - Real Effective Exchange Rate,

ht - Exchange Rate Volatility
Table 3: Estimated short-run coefficients for coffee price function

\begin{tabular}{lcccc}
\hline Variable & Coefficient & $\begin{array}{c}\text { Std. } \\
\text { error }\end{array}$ & $\begin{array}{c}t \text { - } \\
\text { value }\end{array}$ & Prob \\
\hline Intercept, $C$ & $-41.78^{* * *}$ & 5.81 & -2.18 & 0.0000 \\
D (REER) & -0.99 & 4.59 & -0.21 & 0.8283 \\
D (REER (-1)) & $11.56^{* *}$ & 4.60 & 2.51 & 0.0131 \\
D (Ht) & -0.24 & 0.33 & -0.73 & 0.4624 \\
D (Ht (-1)) & $-0.60 *$ & 0.32 & -1.83 & 0.0680 \\
Season 1, $X_{I}$ & $-0.15^{* *}$ & 0.05 & -2.58 & 0.0106 \\
Season 2, $X_{2}$ & -0.02 & 0.05 & 0.41 & 0.6775 \\
Season 3, $X_{3}$ & 0.05 & 0.05 & 0.87 & 0.3827 \\
CointEq $(-1) *$ & $-0.45^{* * *}$ & 0.06 & -7.18 & 0.0000 \\
\hline Source: Authors. *, **, *** means significant at 10, 5 and 1\% \\
prob. levels, respectively. \\
D (REER) - differentiated real effective exchange rate, \\
D (REER (-1) - lagged differentiated REER, \\
D (Ht) - differentiated exchange rate volatility, \\
D (Ht (-1)) - lagged differentiated Ht
\end{tabular}

The results show that season one (January to March) $\left(X_{l}\right)$ has a negative and significant effect on Rwandan coffee export prices at a 5\% significance level. The partial elasticity of Rwandan coffee export prices with respect to season one was found to be -0.15 . This means that in the presence of season one, coffee prices decreased by $15 \%$. The error correction term is negative and significant thereby affirming the existence of co-integration among the variables in the short term. The coefficient of the error correction term implies that around $45 \%$ of the disequilibrium is corrected within a month, as the frequency of the data is monthly. Since the error correction term is significant and large, the speed of adjustment towards the long-run equilibrium is therefore high. The speed adjustment to long run equilibrium implies the limited effect of short-run shocks on Rwandan coffee price.

\section{Effect of Exchange Rate Fluctuation on Volumes of Coffee Exports}

Analysis of the long-run relationship between coffee export volumes and industrial production, real exchange rate, and exchange rate volatility

Table 4 presents the long-run coefficients estimated for the coffee export function. The results indicate that industrial production of the importing country had a significant and positive long-run influence on coffee export volumes. A $1 \%$ increase in the income of the trading partner resulted in a $26.94 \%$ increase in the volume of coffee exports. This may be attributed to the adequate adjustment in the importation of coffee when incomes increase such that an increase in revenues may still increase imports. On the other hand, a long-run increase in the trading partners' incomes may direct resources towards other highly productive products and reduce domestic coffee production, thereby increasing the number of coffee imports from Rwanda. This finding is consistent with Mwansakilwa et al. (2013) who found a positive and significant association between Zambian flower export volumes and the industrial production of Germany, the Netherlands, and the United Kingdom. 
Table 4: Estimated long-run coefficients for coffee export volumes function

\begin{tabular}{lcccc}
\hline Variable & Coefficient & Std. error & $t$-value & Prob. \\
\hline Industrial production (IP) & $26.93^{* * *}$ & 3.46 & 7.78 & 0.00 \\
Real effective exchange rate (REER) & 7.40 & 5.63 & 1.31 & 0.19 \\
Exchange rate fluctuation $\left(h_{t}\right)$ & $-44.44^{* * *}$ & 1.59 & -2.79 & 0.00 \\
Trend & $-0.05^{* * *}$ & 0.00 & -9.32 & 0.00 \\
\hline
\end{tabular}

Source: Authors. *** means significant at $1 \%$ probability level

Exchange rate volatility was negative and significantly associated with the long-run elasticity of Rwandese coffee exports. A $1 \%$ increase in exchange rate volatility resulted in a $44.44 \%$ longrun decrease in coffee export volumes. Davis et al. (2014) reported similar results by indicating that the long-run exchange rate volatility was negative and significantly associated with broiler trade between the top ten world broiler importer and exporter countries. Similarly, Kohansal and Akbari (2013) also indicated that exchange rate volatility had a long-term positive effect on medicinal plant exports in Iran. However, Fedoseeva (2016) noted that the volumes of exports were less affected, compared to export values, by exchange rate volatility between European Union (EU) country members. In contrast to this study, Obi et al. (2013) and Goudarzi et al. (2012) found that exchange rate volatility was positively associated with South African citrus and Iranian agricultural exports, respectively.

Analysis of the short-run relationship between coffee export volumes and industrial production, real exchange rate, and exchange rate volatility Table 5 presents the short-run coefficients estimated from the coffee export function. The previous month's export volumes were positive and signifi cantly associated with the current level of coffee export volumes. The coefficient of the lagged exports implies that a $1 \%$ increase in the previous month's coffee export volume leads to an augmentation in the current coffee export volume by $5.14 \%$ in the short run. This may be due to earlier performance on the international market. If a nation exported more in the prior months and gained profit, then it increases the volume of exports in the current period.

The real income or industrial production of the importing country positively and significantly influenced the volume of coffee exports in the short run. One percent increase in the importing country's real income increased the short-run coffee export volumes by 38.47 . The finding corroborates the results by Tandrayen-ragoobur and Emamdy (2011) who indicated a positive effect of importing country's real income on Mauritius agricultural exports in the short run. Similarly, Goudarzi et al. (2012) found a positive and significant relationship between Iranian pistachio export volumes and importing country's real income. The results also showed that the previous period (months) exchange rate fluctuation (shock) was positive and statistically significant in the shortrun, which means that it had substantial influence concerning the same previous months on coffee export volumes. So, a $1 \%$ increase in exchange rate shock in the prior month increases coffee exports.
Table 5: Estimated long-run coefficients for coffee export volumes function

\begin{tabular}{lllll}
\hline Variable & Coefficient & $\begin{array}{c}\text { Std. } \\
\text { error }\end{array}$ & $\begin{array}{c}t- \\
\text { value }\end{array}$ & Prob. \\
\hline Intercept, $C$ & $-4921.39^{* * *}$ & 662.37 & -7.43 & 0.0000 \\
D (CP(-1)) & $5.14^{* * *}$ & 0.80 & 6.40 & 0.0000 \\
D (IP) & $38.47^{*}$ & 18.11 & 2.12 & 0.0383 \\
D (REER) & 42.25 & 80.76 & 0.52 & 0.6030 \\
D (ht) & -3.81 & 5.82 & -0.65 & 0.5147 \\
Season 1, $X_{1}$ & -1.17 & 2.48 & -0.47 & 0.6388 \\
Season 2, $X_{2}$ & 0.59 & 2.36 & 0.24 & 0.8039 \\
Season 3, $X_{3}$ & $4.79^{*}$ & 2.67 & 1.79 & 0.0786 \\
CointEq (-1)* & $-6.39^{* * *}$ & 0.86 & -7.43 & 0.0000 \\
\hline Source: Authors. *, *** ${ }^{* *}$ (on variable & numbers) & means \\
significant at 10 and 1\%, respectively. & & \\
D (CP(-1)) - lagged differentiated coffee export price, & \\
D (IP) - differentiated industrial production, & \\
D (REER) - differentiated real effective exchange rate, \\
D (Ht) - differentiated exchange rate volatility,
\end{tabular}

There are at least two reasons to explain the Rwandan coffee export sensitivity to exchange rate fluctuation. First, Rwanda's agricultural export crops such as coffee are relatively import-intensive. That is, the production of Rwanda's exportable agricultural commodities or products is highly dependent on a considerable importation of inputs such as pesticides and fertilizers. Exchange rate shocks create uncertainty due to heavy dependence on imported intermediate inputs in the agricultural sub-sector. Second, the smallholder nature of the Rwandese agriculture and agribusinesses also undermines coffee export volumes.

The seasonality of coffee exports positively and significantly influenced the Rwandan coffee exports at a $10 \%$ significance level. Season three had a positive short-run effect on the current coffee export. This can be cautiously interpreted to mean that the occurrence of season three is likely to increase coffee export volumes by $4.79 \%$. The negative and significant error correction term affirmed that the variables were co-integrated. The error correction term coefficient implied that $63.96 \%$ of the export disequilibrium was corrected once a month because the frequency of the data was monthly. Also, the enormous and significant error correction term suggests a high speed of adjustment towards the long-run equilibrium.

\section{CONCLUSION}

Rwanda's strategy for a steady growth in coffee export volumes and revenues is to increase sales of specialty coffee. However, global coffee prices are often volatile and Rwanda has little control over fluctuating global prices. From 2000 till recently, the share of coffee exports to the GDP has considerably been fluctuating. This study investigated the effect of exchange rate volatility on Rwanda coffee price 
and export volumes. The results showed that coffee prices increased in long and short run due to the volatility of exchange rate. The exchange volatility also led to the decrease in coffee export volumes in the long run. The findings also show that the real income in importing countries increased coffee prices in the long run and coffee export volumes in the long run and the short run. In order to stabilize the exchange rate and avoid its bad effects on the coffee price and export volumes, there should be the review of monetary policy and the adoption of the hedging system in Rwanda coffee trade. The currency stabilization can be the answer by using discretionary monetary policy. This policy would allow the policy makers to react on time according to the existence, degree and likely effects of exchange rate fluctuation for coffee commodity while implementing trade policies. In the long run, economic policies aimed at stabilizing the exchange rate are likely to increase the volumes of coffee and tea exports from Rwanda. Producers and firms in coffee sector should increase efficiency and aggressively search for niche markets to boost competitiveness. To avoid exchange rate risk in the short run, firms should require hedging which could involve of taking of a position, by obtaining a cash flow, an asset or a contract; including a forward-looking contract that will rise in value and offset a fall in the value of an existing contract.

\section{REFERENCES}

Broka S., Giertz A., Christensen G., Hanif C. and Rasmussen D. (2016). Tajikistan: Agricultural sector risk assessment. Agriculture Global Practice Technical Assistance Paper, World Bank, Washington, DC. Available at: http:/hdl.handle.net/10986/23765

Davis C.G., Muhammad A., Karemera D. and Harvey D. (2014). The impact of exchange rate volatility on world broiler trade. Agribusiness, 30 (1), 46-55. https://doi.org/10.1002/agr.21366

De Grauwe P. (1988). Exchange rate variability and the slowdown in growth of international trade. IMF Working Papers No. 87/38, 35 (1), 63-84. Available at: https://ssrn.com/abstract=884746

Dickey D. and Fuller W. (1979). Distribution of the estimators for autoregressive time series with a unit root. $J$. Am. Stat. Assoc., 74 (366), 427-431.DOI: $10.2307 / 2286348$

Faridi M.Z. (2012). Contribution of agricultural exports to economic growth in Pakistan. Pak. J. Commer. Soc. Sci., 6 (1), 13-34

Fedoseeva S. (2016). Same currency, different strategies: The (asymetric) role of the exchange rate in shaping European Agri-food Exports. Appl. Econ., 48 (11), 1005-1017

Glosten L.R., Jagannathan R. and Runkle D.E. (1993). On the relation between the expected value and the volatility of the nominal excess returns on stocks. $J$. Finance, 48 (5), 1770-1801. https://doi.org/10.1111/ j.1540-6261.1993.tb05128.x

Goudarzi M., Khanarinejad K. and Ardakani Z. (2012). Investigation the role of exchange rate volatility on Iranian pistachio exports (Case study: date, pistachio and saffron). AGRIS Online Papers Econs. Informatics, 4 (1), 1-7

Gujarati D.N. and Porter D.C. (2009). Basic Econometrics ( $5^{\text {th }}$ ed.), McGraw Hill Book Company, New York
Hendry D.F. and Juselius K. (2001). Explaining cointegration analysis: Part II. Energy J., 21 (1), 1-42. Available at: http://www.jstor.org/stable/41322853

Hochman G., Rajagopal D., Timilsina G. and Zilberman D. (2011). The role of inventory adjustments in quantifying factors causing food price inflation. Policy Research Working Paper Series No. 5744, The World Bank

Kantike I. and Eglite A. (2013). Factors affecting wheat bread prices. Econ. Sci. Rural Dev., 30, 153-158

Kenen P. and Rodrik D. (1986). Measuring and analyzing the effects of short-term volatility in real exchange rates. Rev. Econ. Stat., 68 (2), 311-315. https://doi.org/10.2307/1925511

Kohansal M.R. and Akbari S.M.R. (2013). Effect of exchange rate fluctuations on export of medicinal plants using the ARDL approach. Int. J. Agron. Plant Prod., 4 (11), 3083-3088

Maddala G.S. (1992). Introduction to Econometrics (2 ${ }^{\text {nd }}$ ed.), Macmillan Publishing Company, New York

McKenzie M.D. (1999). The impact of exchange rate volatility on international trade flows. J. Econ. Surveys, 13 (1), 71-106

MINAGRI (2020). Annual Report 2019-2020. Ministry of Agriculture \& Animal Resources, Kigali, Rwanda

MINAGRI (2021). Rwandan coffee ranked among the best of the best globally. Retreived 20/05/21 from https://www.minagri.gov.rw/updates/news-details/rwan dan-coffee-ranked-among-the-best-of-the-best-globally

Mukunzi S. (2004). Monetary Policy Strategy in Rwanda. Masters Thesis, The University of Kwazulu Natal, Durban, South Africa

Mwansakilwa C., Tembo G. and Mugisha J. (2013). Growth and competitiveness of non-traditional agricultural exports in Zambia. Modern Econ., 4 (11), 794-808. https://doi.org/10.4236/me.2013.411085

NAEB (2011). Annual Report 2010. National Agric. Export Dev. Board (NAEB), Kigali, Rwanda

NAEB (2019). NAEB strategic plan 2019-2024. National Agric. Export Dev, Board, Kigali, Rwanda

NBR (2015). Recent economic and financial developments and monetary policy orientation in 2015 Q3. National Bank of Rwanda. Kigali, Rwanda

NISR (2015). Seasonal Agricultural Survey. National Institute of Statistics of Rwanda (NISR), Kigali, Rwanda

Obi A., Ndou P. and Peter B. (2013). Assessing the impact of exchange rate volatility on the competitiveness of South Africa's agricultural exports. J. Agric. Sci., 5 (10), 227-250. https://doi.org/10.5539/jas. v5n10p227

Pesaran M.H., Shin Y. and Smith R.J. (2001). Bounds testing approaches to the analysis of level relationships. J. Appl. Econ., 16 (3), 289-326. https://doi.org/ 10.1002/jae.616

Pozo S. (1992). Conditional exchange rate volatility and the volume of international trade: Evidence from the early 1900s. Rev. Econ. Stat., 74 (2), 325-329. https://doi.org/10.2307/2109665

RDB (2021). Rwanda export products/coffee. Rwanda Development Board. Retrieved 01 May 2021 from: https://rdb.rw/

Taghavi N. and Torkamani J. (2014). An examination of transitional effect of exchange rate on export price of dried fig in Fars province. J. Agric. Econ. Res., 5 (20), 43-60

Tandrayen-ragooburV. and Emamdy V.N. (2011). Does exchange rate volatility harm exports? Evidence from Mauritius. J. Emerg. Trends Econ. Manage. Sci., 2 (3), 146-155

World Bank Group (2019). Rwanda systematic country diagnostic. World Bank, Washington DC. Available at: https://openknowledge.worldbank.org/handle/109 86/32113 